\title{
FIRST RECORD OF MASTOPHORUS MURIS (GMELIN, 1790) (Nematoda: SpirUROIDEA) from a WILD hOSt IN SOUTH AMERICA
}

\author{
ROJAS M. DEL C.* \& DIGIANI M.C.**
}

\begin{abstract}
Summary:
Mastophorus muris (Gmelin, 1790) (Nematoda: Spiruroidea) is reported parasitizing the grey leaf-eared mouse Graomys griseoflavus (Waterhouse, 1837) (Rodentia: Sigmodontinae) from the province of La Pampa, Argentina. The distinct position of Mastophorus (Spirocercidae: Mastophorinae) and Protospirura (Spiruridae), sometimes still confused, is again confirmed. The pattern of pseudolabial teeth la large central tooth with smaller teeth on each side), which seems to be rather stable in all known descriptions, is here confirmed with the aid of scanning electron microscopy. The finding represents the first record of the species in Argentina, but also from a wild host in South America. This indicates an expansion of the distribution range of the species, which, in the subcontinent, was hitherto restricted to domestic rodents.
\end{abstract}

KEY WORDS : Mastophorus muris, Graomys griseoflavus, Argentina.

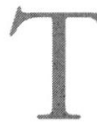
The nematode Mastophorus muris (Gmelin, 1790) (Spiruroidea: Spirocercidae: Mastophorinae) is a cosmopolitan species parasitizing mainly wild and urban rodents, but also other less frequent hosts such as marsupials and carnivores (Baylis, 1927; Smales, 1995; Torres et al., 1998, 2001). It has also been observed parasitizing lemurians in Madagascar (Chabaud, pers. comm.). During an endoparasitological research on rodents of La Pampa (Argentina), some nematodes identified as $M$. muris were found in the stomach of a Graomys griseoflavus (Waterhouse, 1837) (Sigmodontinae). This host inhabits xeric habitats and was occasionally recorded from cultivated fields in Bolivia, Paraguay, Brazil and Argentina, and was considered as a strictly herbivorous species (Redford \& Eisenberg, 1992). Its parasitic fauna is rather poorly studied, only three species of Nippostrongylinae (Nematoda, Heligmonellidae) have been recently described in two populations from the province of San Luis,

\footnotetext{
* Facultad de Ciencias Exactas y Naturales, Universidad Nacional de La Pampa, Av. Uruguay 151, (6300) Santa Rosa, Argentina.

** División Zoología Invertebrados, Museo de La Plata, Paseo del Bosque s/n, (1900) La Plata, Argentina.

Corresponding author: M.C. Digiani.

E-mail: cdigiani@netverk.com.ar
}

Résumé : Première MENTION DE MASTOPHORUS MURIS (GMELIN, 1790) (Nematoda: SpIRUROIDEA) CHEZ un hÔte SAuvage d'AMÉRIQUe DU SUD

Mastophorus muris (Gmelin, 1790) (Nematoda: Spiruroidea) a été retrouvé chez Graomys griseoflavus (Waterhouse, 1837) (Rodentia: Sigmodontinae) dans la province de La Pampa Argentine. La validité de Mastophorus/Spirocercidae: Mastophorinael, parfois encore confondu avec Protospirura (Spiruridae), est une nouvelle fois confirmée. La disposition des dents pseudolabiales (petites dents situées de part et d'autre d'une grande dent centrale), qui semble être assez constante dans toutes les descriptions connues de l'espèce, est confirmée à l'aide du microscope électronique à balayage. Il s'agit de la première mention de l'espèce en Argentine, et de plus chez un hôte sauvage en Amérique du Sud. Ceci met en évidence l'expansion de l'espèce qui, jusqu'à présent, n'était connue que chez des rongeurs domestiques dans le sous-continent.

MOTS CLÉS : Mastophorus muris, Graomys griseoflavus, Argentine.

Argentina (Digiani \& Durette-Desset, 2003). The present contribution provides the first record of $M$. muris from Argentina and from a wild host in South America, and Graomys griseoflavus constitutes a new host record for the species. In addition, the pseudolabial lobes, teeth, and pattern of male caudal papillae are described and illustrated with the aid of scanning electron microscopy.

\section{MATERIALS AND METHODS}

7 he single specimen of Graomys griseoflavus was captured with Sherman trap in Colonia Roca $\left(36^{\circ}\right.$ 54' S-64 $\left.30^{\prime} \mathrm{W}\right)$, Department of Toay, Province of La Pampa, Argentina, on August 2000. It was killed with ether and the body preserved in $70 \%$ ethanol. The nematodes collected from stomach were fixed in hot $70 \%$ ethanol and clarified in lactophenol for identification under light microscope. Four males were dehydrated in an ethanol series, dried by the critical point technique and examined in a JEOL JSM T100 scanning electron microscope. Specimens are deposited in the Helminthological Collection of the Museo de La Plata, La Plata, Argentina, No 5062. 


\section{RESULTS}

T Twenty-four adult nematodes (12 males, 12 females) were recovered. Morphological characters and measurements (in millimetres) of the studied specimens are as follows.

General: head clearly separated from the body; head cuticle smooth, body with strong transverse striation (Fig. 1). Mouth opening circular, surrounded by two lateral pseudolabia, each one composed of one lateral and two submedian lobes, equal in size. Single pair of cephalic papillae at base of each pseudolabium. Outlet of amphids at base of lateral lobes of pseudolabia (Fig. 2). Distal margin of each lobe bearing nine well-developed teeth. Teeth unequal in size, showing same pattern in both lateral and submedian lobes: three large teeth alternating with six smaller ones, which are grouped by three, giving a symetrical arrangement of type 1-3-1-3-1 (Figs 3-4).

Males: $(n=12)$ : 9.0-16.0 (12.6) long. Buccal capsule $0.15-0.19$ (0.17) long and 0.16-0.24 (0.17) wide. Total oesophagus length $1.4-3.7$ (2.5). Nerve ring, excretory pore and deirids at $0.39-0.41(0.33), 0.27-0.42(0.35)$ and 0.2-0.41 (0.3), respectively, from anterior end. Four pairs pedunculate precloacal papillae and two pairs postcloacal papillae, of which only distal pair pedunculate. Unpaired sessile papilla on anterior margin of cloaca (Fig. 5). Variable number (three to five pairs) of small sessile papillae at distal end of tail (Fig. 6). Right spicule 0.79-1.4 (0.99) long and 0.027$0.05(0.032)$ wide. Left spicule 0.72-1.08 (0.96) long and 0.013-0.05 (0.021) wide. Gubernaculum "V"-shaped, asymmetrical. Tail 0.31-0.51 (0.41) long.

Females: $(n=12)$ 15.7-24.3 (19.8) long. Buccal capsule $0.20-0.31(0.22)$ long and $0.17-0.3(0.24)$ wide. Total oesophagus length 1.7-2.7 (2.34). Nerve ring, excretory pore and deirids at $0.39-0.40(0.40), 0.34-0.49$ (0.44) and 0.23-0.39 (0.31), respectively, from anterior end. Vulva at 4.8-10.9 (8.1) from anterior end (31-44 $\%$ of the body length). Tail 0.10-0.28 (0.21) long. Eggs oval, smooth, thick-shelled, 0.046-0.076 long and 0.0190.046 wide.

\section{DISCUSSION}

M Tastophorus is the only genus in the Mastophorinae, a subfamily of the Spirocercidae (Quentin, 1970, 1971; Chabaud, 1975). The genus was, in the past, placed among the Spirurinae, and often confused with representatives of the genus Protospirura Seurat, 1914, also widespread and parasitic in rodents. Even when several authors clearly stated the differences between both genera based on morphological (Chitwood, 1938) and, especially, onto- genetical characters (Quentin, 1969, 1970, 1971), some confusion still persists. As example, in Brazil, the species reported by Vicente et al. (1997), as Protospirura columbiana Cram, 1926, and P. muris (Gmelin, 1790), both parasitic in Rattus spp. correspond in fact both to M. muris, to which they were synonymized by Chitwood (1938) and Wertheim (1962). Moreover, the illustration of the anterior extremity of $P$. columbiana (Vicente et al., 1997, Fig. 657, taken from Cram, 1926), is a typical example of an anterior extremity of M. muris.

Mastophorus muris exhibits a wide morphometrical and, in a lesser extent, morphological variability, probably related to the host species and geographical distribution. Specimens from G. griseoflavus are smaller but show little morphological variation when compared to the descriptions by other authors (Cram, 1926; Baylis, 1927; Chitwood, 1938; Johnston \& Mawson, 1938; Wertheim, 1962). In our specimens from one host, all specimens had the same pattern of pseudolabial teeth (1-3-1-3-1). A similar pattern with a central larger tooth seems to be rather constant in this species, as it was also described or illustrated by other authors. Cram (1926) observed "...a large central tooth and at each side four or five smaller teeth" in lateral lobes and "...three teeth at each side of the large central one" in submedian lobes, in specimens that she named Protospirura columbiana, parasitic in Rattus norvegicus from USA. Baylis (1927) reported "... a large median tooth and three or four smaller teeth on either side of the median tooth" for the specimens that he named Protospirura marsupialis, found in Trichosurus vulpecula from Australia. Wertheim (1962), who studied several specimens parasitic in Rattus spp. from Israel and Australia, described the pattern as quite variable, having in most instances, a large, centrally placed tooth and a variable number of teeth, often bifid, on either side of the large tooth. Quentin (1970) who reproduced experimentally the life cycle of $M$. muris from Apodemus sylvaticus, described the adults as having 9-11 teeth on each labial lobe, and illustrated a lateral lobe with a central larger tooth.

In spite of its wide distribution range, the only previous reports of M. muris from South America come from Rattus spp. from different urban sites in Brazil (Vicente et al. 1997, see above). In the rest of its distribution range, the species was known either from domestic rodents as from other wild hosts. In Australia, it was reported from marsupials (Trichosurus vulpecula, Hypsiprymnodon moschatus) and endemic wild rodents (Rattus fuscipes, R. sordidus) (Baylis, 1927; Wertheim, 1962; Smales, 1992, 1995). Smales (1992) suggested that M. muris may have arrived in Australia with its hosts Rattus spp. (R. norvegicus and $R$. rattus). Thus, the transition to the Australian endemic Rattus should have occurred by a phenomenon of capture from the pri- 

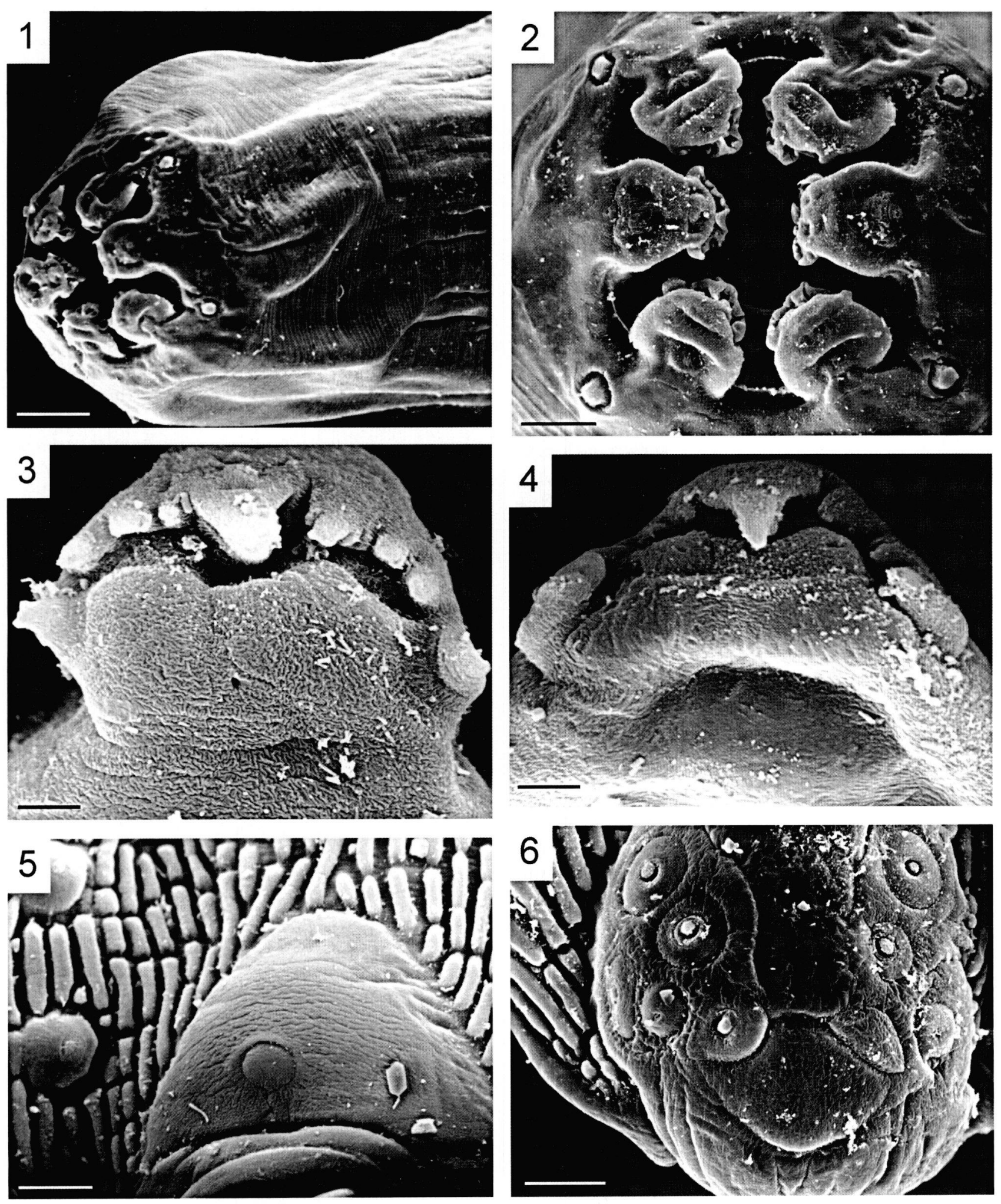

Figs 1-6. - Male of Mastophorus muris (Gmelin) from Graomys griseoflavus (Waterhouse).

1-2, anterior extremity: 1, lateral view; 2, apical view. 3-4, detail of pseudolabial teeth, showing symmetrical arrangement 1-3-1-3-1: 3, lateral lobe; 4 , submedian lobe. 5-6, detail of caudal papillae, ventral view: 5, unpaired precloacal papilla; 6, distal sessile papillae. Scale bars: 1, $50 \mu \mathrm{m} ; 2,5,25 \mu \mathrm{m} ; 3-4,5 \mu \mathrm{m} ; 6,20 \mu \mathrm{m}$. 
mary host, and this is probably the case also in the rest of its distribution.

The present finding from $G$. griseoflavus indicates the expansion of $M$. muris towards the wild environment in South America. In La Pampa, rodents usually leave the cultivated fields in search of food after the summer fires. When they approach to the domestic environment (houses, hangars, silos), the opportunities of infestation become higher by the presence of rats and mice and infested intermediate hosts (cockroaches, dermapterans). Since several sigmodontine species have a similar behaviour, it is likely that new cases of host capture be reported in next time.

\section{ACKNOWLEDGEMENTS}

W e wish to thank A. De Niro for technical assistance, E. Justo and M. Kin for help in the identification of the rodent, and the Servicio de Microscopía Electrónica de Barrido de la Facultad de Ciencias Naturales y Museo, Universidad Nacional de La Plata, for producing SEM photographs. Special thanks are due to Mr. Prof. A.G. Chabaud (MNHN) for providing unpublished data and for valuable help and discussion, and to Dr O. Bain (MNHN) for helpful suggestions which largely improved the original version of the manuscript.

\section{REFERENCES}

BAYLIS H.A. Some new parasitic nematodes from Australia. Annals and Magazine of Natural History, 1927, 20, 215225.

Chabaud A.G. Keys to genera of the order Spirurida, in: $\mathrm{CIH}$ Keys to the Nematode parasites of Vertebrates. Anderson R.C., Chabaud A.G. \& Willmott S. (eds.). Common Agricultural Bureaux, Farnham Royal, Bucks, England, 1975, No 3, 29-58

Chitwood B.G. The status of Protospirura vs. Mastophorus, with consideration of the species of these genera. Livro Jubilar do Professor Lauro Travassos, 1938, 115-118.

CRAm E.B. A new nematode from the rat and its life history. Proceedings of the United States National Museum, 1926 $68,1-7$.

Digiani M.C. \& Durette-Desset M.-C. Two new species of Nippostrongylinae (Nematoda: Trichostrongylina: Heligmonellidae) from the grey leaf-eared mouse Graomys griseoflaus (Sigmodontinae) in Argentina. Parasite, 2003, 10, 21-29.

Johnston T.H. \& Mawson P.M. Some nematodes from Australian marsupials. Records of the South Australian Museum, 1938, 6, 187-198.

Quentin J.-C. Cycle biologique de Protospirura muricola Gedoelst, 1916 (Nematoda Spiruridae). Annales de Parasitologie Humaine et Comparée, 1969, 44, 485-504.
Quentin J.-C. Morphogenèse larvaire du Spiruride Mastophorus muris (Gmelin, 1790). Annales de Parasitologie Humaine et Comparée, 1970, 45, 839-855.

QuENTIN J.-C. Sur les modalités d'évolution chez quelques lignées d'Helminthes de Rongeurs Muroidea. Cabiers ORSTOM, série Entomologie médicale, Parasitologie, 1971, 9, $103-176$.

REDFORD K.H. \& EINSENBERG J.F. Mammals of the Neotropics, The Southern Cone. The University of Chicago press, 1992, Vol. 2, 431 pp.

SMALES L.R. A survey of the helminths of Rattus sordidus, the canefield rat, together with a description of Ancistronema coronatum n. g., n. sp. (Nematoda: Chabertiidae). Systematic Parasitology, 1992, 22, 73-80.

SMALES L.R. Mastophorus muris (Nematoda: Spirocercidae) from the musky rat-kangaroo, Hypsiprymnodon moschatus. Transactions of the Royal Society of South Australia, 1995, $119,95$.

Torres J., García-Perea R., Gisbert J. \& Feliú C. Helminth fauna of the Iberian lynx, Lynx pardinus. Journal of Helmintbology, 1998, 72, 221-226.

Torres J., Miquel J. \& Motje M. Helminth parasites of the eurasian badger (Meles meles L.) in Spain: a biogeographic approach. Parasitology Research, 2001, 87, 259-263.

Vicente J.J., Rodrigues H.O., Gomes D.C. \& Pinto R.M. Nemátoides do Brasil. Parte V: Nemátoides de Mamíferos. Revista Brasileira de Zoologia, 1997, 14 (Suppl. 1), 1-452.

WeRTHEIM G. A study of Mastophorus muris (Gmelin, 1790) (Nematoda: Spiruridae). Transactions of the American Microscopical Society, 1962, 81, 274-279.

Reçu le 22 avril 2003 Accepté le 7 juillet 2003 